\title{
Safety assessments of subcutaneous doses of aragonite calcium carbonate nanocrystals in rats
}

\author{
Alhaji Zubair Jaji • Zuki Abu Bakar Zakaria • Rozi Mahmud • \\ Mohamad Yusof Loqman • Mohamad Noor Mohamad Hezmee • Yusuf Abba • \\ Tijani Isa $\cdot$ Saffanah Khuder Mahmood
}

Received: 28 April 2016/Accepted: 10 April 2017 / Published online: 11 May 2017

(C) The Author(s) 2017. This article is an open access publication

\begin{abstract}
Calcium carbonate nanoparticles have shown promising potentials in the delivery of drugs and metabolites. There is however, a paucity of information on the safety of their intentional or accidental over exposures to biological systems and general health safety. To this end, this study aims at documenting information on the safety
\end{abstract}

A. Z. Jaji · Z. A. B. Zakaria · M. N. M. Hezmee •

S. K. Mahmood

Department of Veterinary Preclinical Science, Faculty of

Veterinary Medicine, Universiti Putra Malaysia, Serdang,

Malaysia

A. Z. Jaji

Department of Veterinary Anatomy, Faculty of Veterinary

Medicine, University of Ilorin, Ilorin, Nigeria

Z. A. B. Zakaria $(\varangle) \cdot$ T. Isa

Institute of Bioscience, Universiti Putra Malaysia, 43400 Serdang,

Selangor, Malaysia

e-mail: zuki@upm.edu.my

Z. A. B. Zakaria

e-mail: mdzukiabubakar@gmail.com

R. Mahmud

Department of Imaging, Faculty of Medicine \& Health Science, Universiti Putra Malaysia, Serdang, Malaysia

M. Y. Loqman

Department of Companion Animal Medicine and Surgery, Faculty of Veterinary Medicine, Universiti Putra Malaysia, Serdang,

Malaysia

Y. Abba

Department of Veterinary Pathology and Microbiology, Faculty of Veterinary Medicine, Universiti Putra Malaysia, Serdang,

Malaysia of subcutaneous doses of biogenic nanocrystals of aragonite polymorph of calcium carbonate derived from cockle shells (ANC) in Sprague-Dawley (SD) rats. ANC was synthesized using the top-down method, characterized using the transmission electron microscopy and field emission scanning electron microscope and its acute and repeated dose 28-day trial toxicities were evaluated in SD rats. The results showed that the homogenous $30 \pm 5 \mathrm{~nm}$-sized spherical pure aragonite nanocrystals were not associated with mortality in the rats. Severe clinical signs and gross and histopathological lesions, indicating organ toxicities, were recorded in the acute toxicity $\left(29,500 \mathrm{mg} / \mathrm{m}^{2}\right)$ group and the high dose $\left(5900 \mathrm{mg} / \mathrm{m}^{2}\right)$ group of the repeated dose 28-day trial. However, the medium- $\left(590 \mathrm{mg} / \mathrm{m}^{2}\right.$ body weight $)$ and low $\left(59 \mathrm{mg} / \mathrm{m}^{2}\right.$ )-dose groups showed moderate to mild lesions. The relatively mild lesions observed in the low toxicity dosage group marked the safety margin of ANC in SD rats. It was concluded from this study that the toxicity of $\mathrm{CaCO}_{3}$ was dependent on the particulate size $(30 \pm 5 \mathrm{~nm})$ and concentration and the route of administration used.

Keywords $\mathrm{CaCO}_{3} \cdot$ In vivo $\cdot$ Nanotoxicity . Cockle shell $\cdot$ Aragonite

\section{Introduction}

Cockle (Anadara granosa) is a group of generally small, edible, saltwater clams, marine bivalve molluscs of the family Cardiidae shell. Cockle is by far the most vital 
species cultured, and one of the most common sources of calcium carbonate found in Malaysia. It easily fulfils the increasing demand of biomaterials due to its low cost and availability (Combes et al. 2006; Hoque et al. 2013). The cockle shells contain more than $98 \%$ calcium carbonate and thus have the potential to be a starting material for the development of biomaterials for orthopaedic applications (Awang-Hazmi et al. 2007).

The aragonite polymorph of calcium carbonate is a less thermodynamically stable and a less available form of crystalline calcium carbonate polymorph synthesized in the laboratory. The size and shape of aragonite are strongly dependent on the preparation methods and conditions (Wang et al. 1999). Due to the huge striking properties of the aragonite nanoparticles as a material of biomedical importance, researchers have paid huge attention on invention of methods for its synthesis and usage (Guo et al. 2007; Wang et al. 2006).

Nanoparticles (NPs) are nanoobjects with all external dimensions in the nanoscale, where the lengths of the longest and the shortest axes of the nanoobject do not differ significantly (ISO/TS 2015). NPs have properties that are quite unique from their sourced bulk materials. Their sizes are inversely proportional to their surface/ volume ratio and chemical reactivity; this makes them interesting materials in research and applications. Thus, significantly improving many fields of human endeavours (Gwinn and Vallyathan 2006; Hristozov and Malsch 2009; Morose 2010; Moorthi et al. 2011). Though renowned with numerous benefits, there are still growing concerns that deliberate or accidental human exposures to some types of NPs, through environmental contamination and distorted ecosystem, may lead to significant adverse health effects (Colvin 2003; Oberdorster et al. 2005; The Royal Society 2004). The fact that the potentials of exposure to NPs are bound to increase, just as their usage, raises pertinent concerns about their health safety (Drobne 2007). These concerns lead to the emergence of a new branch of research in toxicology called nanotoxicology. Toxicology is the study of sequence of events associated with the acquaintance, progress, distribution, metabolism and culminating in cellular macromolecular, DNA or proteins, interactions and the associated toxic manifestations of poisons (Hodgson 2010). Nanotoxicology aims at (i) studying the properties of nanomaterials in toxicity studies; (ii) studying the possible detrimental effects of exposures to NPs; and (iii) recommending comprehensive test protocols for in human and environmental risk assessment of nanomaterials (Oberdorster et al. 2005; Drobne 2007; Nel et al. 2006).

With the recent advancement in the use of NPs in drug delivery systems, there is an urgent need for their risk assessment. Risk assessment involves data collection, analysis and interpretation on the risk of a given entity. Evaluations of dose and hazard of a chemical substance mark the first line of action in its risk assessment. However, such assessments are often strongly complicated by the size and surface dependent behaviour of the tested substances (Elsaesser and Howard 2012). Time- or incident-dependent changes for exposure of NPs in the system have been observed to be best for the evaluation of systemic biology. The interactions and relations following such exposures are often described in biological pathways and networks as preludes to systemic study of nanotoxicity (Kitano 2002).

The respiratory, integumentary and digestive systems have been identified as the three main entry routes of NPs into the body (Stern and McNeil 2008). The fact that NPs could gain access to, and accumulate in, other organs through blood, by biodistribution and bioaccumulation, poses major concerns (Borm et al. 2006; Sayes and Warheit 2009). Apart from blood, phagocytosis and endocytosis of NPs by body cell have also been observed to play very important roles in further spread to distant organs (Garnett and Kallinteri 2006; Yacobi et al. 2010; Greulich et al. 2011). Irrespective of natural barriers, low concentrations of NPs have been found in the liver, the spleen, the heart and the brain ( $\mathrm{Ji}$ et al. 2006; Oberdorster et al. 2002). There are unanswered queries on the fate of NPs and their residues in the body or whether they accumulate in certain organs. The full mechanisms behind certain in vivo toxicological findings need to be elucidated. For instance, the mechanism of their excretion through the urine is still unclear and there is a need for assessing their possible roles in the blockage of the excretory systems. (Elsaesser and Howard 2012).

The continuous assemblage of engineered NPs as drug carrier systems stresses the need for a full understanding of their health safety (Kroll et al. 2012). Though calcium carbonate is regarded as being generally safe and is now gaining acceptance as a successful nanocarriers for subcutaneous delivery of biologicals (Ueno et al. 2004; He et al. 2008; Higaki et al. 2006), there is paucity of information on the possible toxicity that may arise from deliberate or accidental exposure to its high doses. This study aims at evaluating the acute 
and subchronic toxicity of subcutaneous doses of cockle shell-derived aragonite calcium carbonate nanocrystals (ANC) in male and female SD rats, with the view of documenting information on its health safety.

\section{Materials and methods}

\section{Preparation of spherical shaped ANC}

This study adopted and modified the Islam et al. (2012) top-down method of nanoparticle production in syntheses of ANC from cockle shells, towards improving its biocompatibility. Micron aragonite calcium carbonate powder was first prepared from cockle shells. This entailed washing and scrubbing of dirt and tissues off the cockle shells. The cleaned shells were boiled at $100{ }^{\circ} \mathrm{C}$ for $10 \mathrm{~min}$ in HPLC-grade water (resistance $>18 \mathrm{M} / \mathrm{cm}$ ), produced by a Milli-RO6 plus Milli-Q Water System (Organex) and later cooled to room temperature. A second thorough washing with distilled water was also done before oven drying the shells in Memmert UM500 oven (GmbH Co, Germany) at $50{ }^{\circ} \mathrm{C}$ for 7 days. The shells were then powdered finely with mortar and pestle (Agate Top diameter $90 \mathrm{~mm}$ ), ground with a stainless steel blender (Blendor, HCB 550, USA) and sifted using a $75-\mu \mathrm{m}$ aperture sized stainless steel laboratory test sieve (Endecott Ltd., London, England) to get a $75-\mu \mathrm{m}$ diameter sized particles. The coarse unfiltered remnants were further dried in the oven for $10 \mathrm{~h}$, and ground with mortar and pestle and blender and sieved to further reduce their diameter. The produced micron aragonite $\mathrm{CaCO}_{3}$ powder (MAC) was further desiccated in an oven at $50{ }^{\circ} \mathrm{C}$ for 7-day duration for complete dry up. The MAC was then packaged in a Jp Packaging polyethylene plastic bag (Jp Packaging (M) Sdn Bhd).

A measure of $2 \mathrm{~g}$ of the $75 \mu \mathrm{m}$-sized powder was placed in a $100-\mathrm{mL}$ flat bottom flask, $50 \mathrm{~mL}$ of HPLCgrade water (resistance $>18 \mathrm{M} \mathrm{cm}$ ), produced by a MilliRO6 plus Milli-Q Water System (Organex) and $0.5 \mathrm{~mL}$ of dodecyl dimethyl betaine (BS12) (Sigma Aldrich) were added to each flask and stirred vigorously at $1000 \mathrm{rpm}$, in room temperature, for 90 min using a Systematic Multi-Hotplate Stirrer (DH.WMH03506 DAIHAN WiseStir ${ }^{\circledR}$ SMHS Systematic MultiHotplate Stirrers, $3{ }^{\text {a }} 2$ Places 6 Positions, Korean) and a magnetic stirrer bar. The slurry that was obtained from this process was filtered and rinsed with $18.0 \mathrm{~cm}$ sized double ring filter papers (Filtres Fioroni, China). The final products was dried in the Memmert UM500 Oven, $\mathrm{GmbH}$ Co, Germany) for $24 \mathrm{~h}$ at $100{ }^{\circ} \mathrm{C}$ and packed in JP packaging polyethylene plastic bags and stored in moisture free enclosure (at $50^{\circ} \mathrm{C}$ ) for further analysis and usage.

\section{Characterization of ANC}

The transmission electron microscope (TEM) (Hitachi H-7100, Japan) was used to determine the shape and size of ANC. Sample preparation for TEM entailed dispersal of $100 \mu \mathrm{g}$ of ANC powder in $1 \mathrm{~mL}$ of $100 \%$ acetone. This was followed by ultra-sonication (Power Sonic 505, S. Korea) for $30 \mathrm{~min}$. A drop of the supernatant was then placed onto a carbon-covered copper grids placed on a filter paper and left to dry at room temperature. The TEM measurement was made at $150 \mathrm{kV}$.

The field emission scanning electron microscope (FESEM) (JEOL 7600F, JEOL, München, Germany) $\mathrm{GmbH}$ was used to further evaluate the shape and size of ANC. Samples for FESEM analysis were sparingly dispersed on adhesive-coated metallic stub that was then fitted in to the FESEM microscope for the analysis.

ANC was suspended in deionized water and its mean zeta potential was based on dynamic light scattering determined by photon correlation spectroscopy using Zetasizer (Ver. 6.12, serial number MAL1042820, Malvern Instruments Ltd.).

Detailed physicochemical characterization and cytocompatibility of ANC had earlier been determined (Jaji et al. 2017).

\section{In vivo toxicity of $\mathrm{ANC}$}

The protocols for these studies were approved by the Institutional Animal Care and Use Committee (IACUC), Universiti Putra Malaysia (AUP number R002/2014). Rats were procured, from the Animal Resource Unit, University Putra Malaysia (UPM), and kept in the animals housing facility, Faculty of Veterinary Medicine, UPM. They were housed and maintained at constant temperature, with $12 \mathrm{~h}$ light/12 h dark cycles and provided with commercial feed (gold coin mouse pellet) and water ad libitum. The handling of the animals was in adherence with the approved IACUC guidelines. 


\section{Fourteen-day acute toxicity study}

Two consecutive sets of apparently normal 10-week-old female SD rats, two groups (toxicity and control groups) per set (three rats per group), were procured and used for preliminary evaluations of acute toxicity of ANC at two different subcutaneous doses (1770 and $\left.11,800 \mathrm{mg} / \mathrm{m}^{2}\right)$. In the absence of mortality from the two dose trials (14 days per trial), a last set of rats with similar features as the previous ones was administered single subcutaneous doses of $29,500 \mathrm{mg} / \mathrm{m}^{2}$ and closely monitored for signs of toxicity and mortality for 14 days.

\section{Repeated dose 28-day trial}

Four groups, composing of six apparently normal (three males and three females) 6-week-old SD rats, were procured and used for this evaluation. The animals were divided into three different concentrations groups low, medium and high, and were administered daily subcutaneous doses of 59,590 and $5900 \mathrm{mg} / \mathrm{m}^{2}$ of ANC, respectively. An equivalent volume of vehicle was administered to a control group. The animals were closely monitored for signs of toxicity and mortality for 28 days.

\section{Tissues processing}

Bones were fixed in 10\% neutral formalin for 3 days, during which the formalin was changed every $24 \mathrm{~h}$. The bones were transferred to $80 \%$ formic acid for decalcification for 1 week. Decalcified bones and $2 \mathrm{~cm}$ visceral specimens were fixed in $10 \%$ neutral formalin for 3 days for histological slides production. The tissues were then embedded in paraffin and sectioned at $5 \mu \mathrm{m}$ thickness. These sections were transferred onto slides and stained with haematoxylin and eosin (Muhammad et al. 2013). The sections were later observed and captured using the Motic Compound Microscope BA410. The Motic Images Plus 2.0 software was used to analyse the images before they were being captured.

\section{Statistical analyses}

Descriptive (mean and standard deviation (SD) and analytical ( $t$ test and one-way ANOVA with Tukey's post test) statistics were performed using GraphPad Prism version 5.00 for Windows, GraphPad Software,
San Diego, CA, USA. Means of trial doses and control groups were compared at $95 \%$ level of significance.

\section{Results}

\section{Characterization of ANC}

Figures 1 and 2 show the shape and size of ANC as viewed under TEM and FESEM, respectively. The crystals were observed to be spherical in shape and the sizes were $30 \pm 5 \mathrm{~nm}$ in diameter. The zeta potential of ANC was $-17.2 \mathrm{mV}$ (Fig. 3).

Fourteen-day acute toxicity study

\section{Clinical observations}

No mortality was recorded at the end of the experiment. There was no sign of toxicity from the initial doses of the experiment $\left(1770\right.$ and $\left.11,800 \mathrm{mg} / \mathrm{m}^{2}\right)$. However, the dose $\left(29,500 \mathrm{mg} / \mathrm{m}^{2}\right)$ that was eventually used for the study was associated with some toxic signs. The toxicity group showed oedema at the site of injection right from day 3 of the experiment. The rats became anorexic lethargic and dyspnoeic on the sixth day of the experiment. There were also fever, tachycardia and roughened hair coat. These signs advanced in severity in the remaining days of the experiment. The oedema at the site of injection subsided and was replaced by necrosis. The rats showed a serious gangrene lesion at the end of the experiment (Fig. 4).

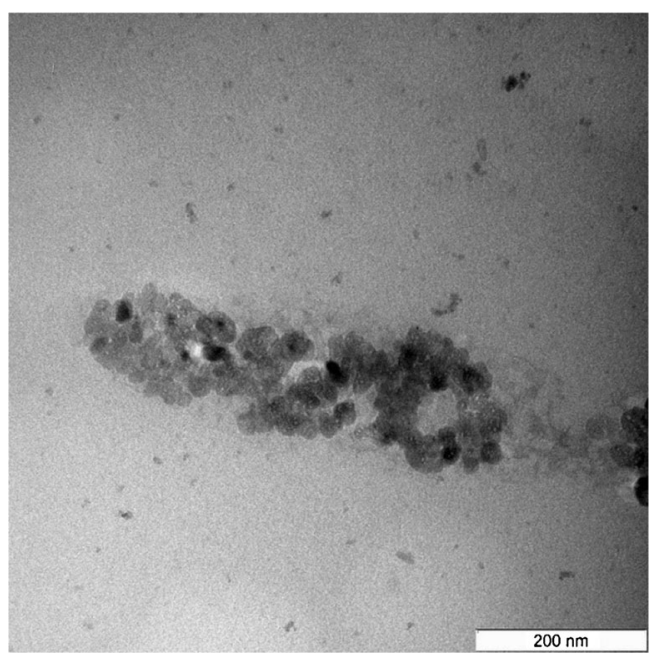

Fig. 1 TEM micrograph of the clear spherical crystals of ANC 


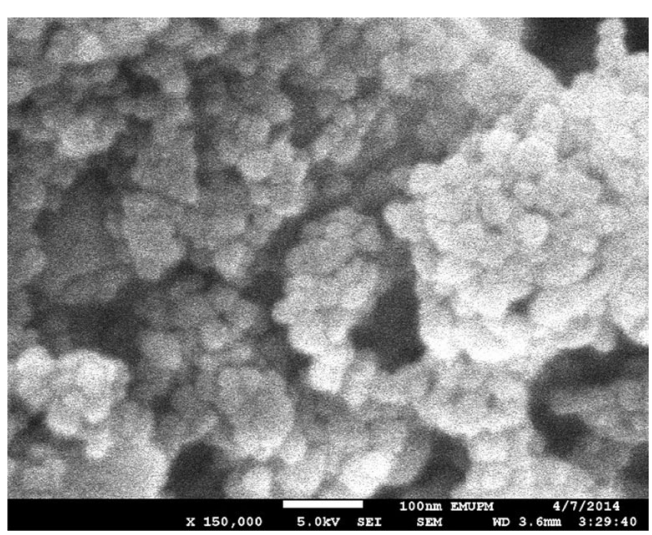

Fig. 2 FESEM micrograph of the clear spherical crystals of ANC

\section{Haematology and serum biochemistry}

Some of the haematological parameters in the toxicity group showed insignificant variations from the control. However, serum biochemistry in the toxicity group showed significant increases in alanine aminotransferase (ALT) $(p<0.001)$, alkaline phosphatase (ALP) $(p<0.05)$, aspartate aminotransferase (AST) $(0.001)$ total bilirubin $(p<0.001)$, creatinine, urea $(p<0.001)$, total protein $(p<0.001)$ and potassium $(p<0.05)$. On the contrary, significant decreases were observed in the levels of calcium $(p<0.001)$, cholesterol $(p<0.05)$ and albumin. Increased levels of ALT, ALP, AST and bilirubin signified liver disease while increased levels of urea and creatinine signified kidney disease. Decreased level of albumin was observed to be due to the inability of the diseased liver to produce albumin. This led to compromised integrity of capillaries and congestion and oedema in tissues. Blood haemogram showed a significant decrease in levels of red blood cells $(p<0.001)$, haemoglobin $(p<0.001)$, packed cell volume (haematocrit) $(p<0.01)$, MCHC $(p<0.05)$ and thrombocytes $(p<0.05)$ all signifying anaemia. The anaemia

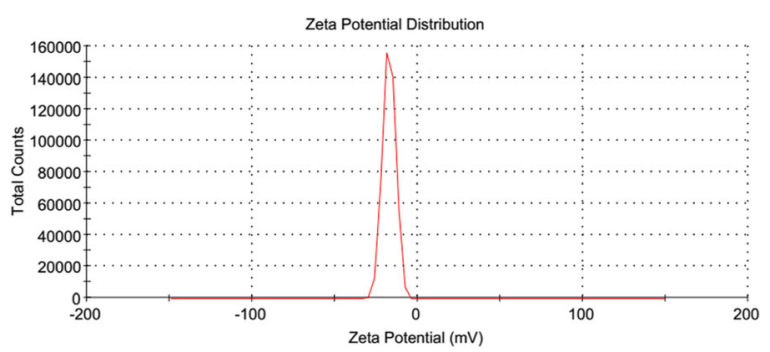

Fig. 3 Zeta potential of ANC (-17.2 mV) was further characterized with compensatory increased levels of MCV $(p<0.05)$ and white blood cells $(p<0.01)$. There was also significant eosinophilia $(p<0.01)$ in effort to contain the systemic spread of ANC (Tables 1 and 2).

\section{Histopathology}

There were granular lesions in the liver, congestion of the heart and the kidneys and polymorphonuclear cell infiltration-associated thickening of alveolar septae in the lungs, pockets of white pulp depletion in the spleen and hypercellularity and cortical and trabecular degenerations in the tibial bone (Fig. 5). The ovaries and cutaneous tissues away from the site of injections were, however, observed to be normal.

Repeated dose 28-day trial

\section{Clinical observations and ophthalmology}

No mortality was recorded at the end of the experiment. However, rats in the toxicity groups showed a dose dependent toxicity signs. There were signs of anorexia, roughened hair coat, lethargy and dyspnoea as the experiment advances. There were also fever and tachycardia and toxic signs of the eyes, characterized by necrotic lesions of the cornea and conjunctivae. The necrosis resulted in halos around both eyes (Fig. 6).

Evaluation of organ to body weight ratios from repeated dose 28-day trial of cockle shell-derived aragonite calcium carbonate nanocrystals

Tables 3 and 4 show the ratios of body and organ weights of SD rats in subchronic toxicity studies, respectively. There was a significant splenomegaly $(p<0.001)$ and significant decreased $(p<0.05)$ in lungs weight in the male of high toxicity $\left(5900 \mathrm{mg} / \mathrm{m}^{2}\right)$ group (Table 4).

\section{Haematology and serum biochemistry}

The serum biochemistry of the female medium $(590 \mathrm{mg} /$ $\mathrm{m}^{2}$ ) and high $\left(5900 \mathrm{mg} / \mathrm{m}^{2}\right)$ toxicity groups showed significant increases $(p<0.001)$ in ALT, ALP and AST levels, associated with liver diseases. There seems to be a negligent effects of the medium and high dosages on serum creatinine levels, as creatinine and urea of the 
male and female rats stabilized between these levels, while only the male showed stabilized urea at these levels (Tables 5 and 6). The medium- and high-dose levels of exposure were also observed to be associated with liver diseases in male rats, to a lesser extent (Table 6$)$. The low toxicity $\left(59 \mathrm{mg} / \mathrm{m}^{2}\right)$ groups of both sexes showed no significant difference $(p>0.05)$ in levels of serum biochemical parameters studied (Tables 5 and 6).

The haemogram of the female medium $\left(590 \mathrm{mg} / \mathrm{m}^{2}\right.$ body weight) and high $\left(5900 \mathrm{mg} / \mathrm{m}^{2}\right)$ toxicity groups showed significant decreases $(p<0.05$ and 0.001$)$ in red blood cells, haemoglobin, haematocrit and mean corpuscular haemoglobin concentration (MCHC). The two dosages were also associated with blood thinning characterized by thrombocytopenia $(p<0.001)$ (Table 5). Similar trends were observed in the male medium $\left(590 \mathrm{mg} / \mathrm{m}^{2}\right.$ body weight) and high $\left(5900 \mathrm{mg} / \mathrm{m}^{2}\right)$ toxicity groups of this study (Table 6). Significant eosinophilia $(p<0.001)$ was also recorded in the female high $\left(5900 \mathrm{mg} / \mathrm{m}^{2}\right)$ toxicity and the male medium $(590 \mathrm{mg} /$ $\mathrm{m}^{2}$ body weight) and high $\left(5900 \mathrm{mg} / \mathrm{m}^{2}\right)$ toxicity $(p<0.05$ and 0.001$)$ groups. The low toxicity groups $\left(59 \mathrm{mg} / \mathrm{m}^{2}\right)$ of both sexes showed no significant changes $(p>0.05)$ in levels of the haemogram parameters studied (Tables 5 and 6).

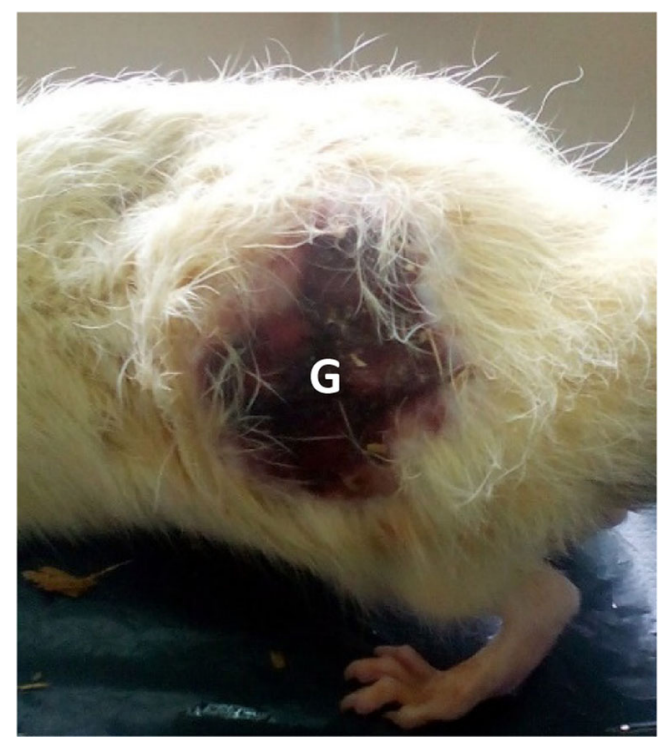

Fig. 4 Gross lesion from 14-day acute toxicity study of $29,500 \mathrm{mg} / \mathrm{m}^{2}$ ANC. Note the roughened hair coat and gangrened tissue, $G$ (blackish discoloration), at the site of injection in one of the rats at day 13 post injection

\section{Gross lesions and histopathology}

There were marked splenomegaly and hepatomegaly in the high toxicity group of both sexes. The hepatomegaly was also associated with fatty infiltration (Fig. 7). The severity of the histopathological lesions in the viscera and bones of the toxicity groups in both sexes were dosage specific, while the gonads showed no significant lesion.

Figure 8 shows lesions, as against normal tissues, from high dosage group of 28-day subchronic toxicity of ANC in SD rats. There were marked fatty cells in the liver due to the inability of the liver to metabolize fats, characteristic of liver damage. The spleen showed no distinction between red pulp and white pulp due to depopulation of the white pulp and hypercellularity. There were macrophages and giant cells infiltration. The kidneys showed multifocal interstitial polymorphonuclear infiltration. The glomeruli showed mild abnormalities. There were vacuolar degenerations and marked degenerations and necrosis of renal tubules. There were generalized congestion and exudates in the lungs. The proximal tibial extremity showed hypercellularity and marked increase in osteoclast population, without commensurate increase in osteoblast population. This led to an attendant marked trabecular and cortical resorption. No significant lesions were associated with the heart and gonads.

Figure 9 shows lesions, as against normal tissues, from medium dosage group of repeated dose 28-day trial of ANC in SD rats. The liver showed generalized mild degeneration without necrosis. The spleen showed large areas of macrophage infiltration and depletion of white pulp areas. There were mild multifocal tubular degeneration and necrosis in the kidneys. The glomeruli showed mild abnormalities. The lungs showed localized congestion and exudation with attendant increase in thickness of the alveolar septae due to elicited interstitial infiltration. There was also mild proliferation of mucosa-associated lymphoid tissue (MALT) cells. The proximal tibial extremity showed hypercellularity, moderate increase in osteoclast population and associated trabecular and cortical resorption. There were no significant lesions in the heart and gonads.

Figure 10 shows lesions, as against normal tissues, from low dosage group of repeated dose 28-day trial of ANC in SD rats. There was granulation of the liver due to the efforts of macrophages in curtailing the spread of 
Table 1 Serum biochemistry of rats in 14-day acute toxicity of $29,500 \mathrm{mg} / \mathrm{m}^{2}$ ANC (mean $\pm \mathrm{SD}$ )

\begin{tabular}{|c|c|c|c|c|c|c|c|}
\hline \multirow[t]{2}{*}{ Parameter } & \multirow[t]{2}{*}{ Unit } & \multicolumn{3}{|l|}{ Control } & \multicolumn{3}{|l|}{ Toxicity } \\
\hline & & Mean & & SD & Mean & & SD \\
\hline Calcium & $\mathrm{mmol} / \mathrm{L}$ & 2.77 & \pm & 0.04 & 2.38 & \pm & $0.02 * *$ \\
\hline Phosphate & $\mathrm{mmol} / \mathrm{L}$ & 2.32 & \pm & 0.15 & 2.54 & \pm & 0.01 \\
\hline Alanine aminotransferase & $\mathrm{U} / \mathrm{L}$ & 49.37 & \pm & 2.22 & 72.17 & \pm & $3.35 * *$ \\
\hline Alkaline phosphatase & $\mathrm{U} / \mathrm{L}$ & 221.30 & \pm & 29.14 & 282.00 & \pm & $13.53 *$ \\
\hline Aspartate aminotransferase & $\mathrm{U} / \mathrm{L}$ & 78.53 & \pm & 6.77 & 139.60 & \pm & $5.97 * *$ \\
\hline Total bilirubin & $\mathrm{umol} / \mathrm{L}$ & 2.07 & \pm & 0.15 & 3.07 & \pm & $0.15 * *$ \\
\hline Cholesterol & $\mathrm{mmol} / \mathrm{L}$ & 5.85 & \pm & 0.32 & 4.58 & \pm & $0.47 *$ \\
\hline Creatinine & umol/L & 34.67 & \pm & 3.79 & 66.33 & \pm & $2.08 * *$ \\
\hline Glucose & $\mathrm{mmol} / \mathrm{L}$ & 5.90 & \pm & 0.70 & 5.97 & \pm & 0.45 \\
\hline Urea & $\mathrm{mmol} / \mathrm{L}$ & 17.53 & \pm & 0.78 & 27.87 & \pm & $0.86^{* *}$ \\
\hline Total protein & $\mathrm{g} / \mathrm{L}$ & 61.30 & \pm & 1.21 & 71.83 & \pm & $1.60 * *$ \\
\hline Albumin & $\mathrm{g} / \mathrm{L}$ & 40.87 & \pm & 3.92 & 29.63 & \pm & $2.70 *$ \\
\hline Sodium & $\mathrm{mmol} / \mathrm{L}$ & 144.30 & \pm & 6.81 & 136.00 & \pm & 3.00 \\
\hline Potassium & $\mathrm{mmol} / \mathrm{L}$ & 3.13 & \pm & 0.21 & 4.17 & \pm & $0.60 *$ \\
\hline Chloride & $\mathrm{mmol} / \mathrm{L}$ & 104.00 & \pm & 3.61 & 99.67 & \pm & 0.58 \\
\hline
\end{tabular}

$n=3$ rats per group

*Significant $(p<0.05)$; **significant $(p<0.01)$

ANC to the liver. There were also areas of periportal infiltration of polymorphonuclear cells. There were pockets of white pulp depletion in the spleen. There was generalized mild degeneration without necrosis of

Table 2 Haemogram of rats in 14-day acute toxicity of $29,500 \mathrm{mg} / \mathrm{m}^{2}$ ANC (mean \pm SD)

\begin{tabular}{|c|c|c|c|c|c|c|c|}
\hline \multirow[t]{2}{*}{ Parameter } & \multirow[t]{2}{*}{ Unit } & \multicolumn{3}{|l|}{ Control } & \multicolumn{3}{|l|}{ Toxicity } \\
\hline & & Mean & & $\mathrm{SD}$ & Mean & & SD \\
\hline Red blood cells & $\times 10^{12} / \mathrm{L}$ & 8.62 & \pm & 0.13 & 7.06 & \pm & $0.09 * * *$ \\
\hline Haemoglobin & $\mathrm{g} / \mathrm{L}$ & 157.00 & \pm & 1.00 & 133.40 & \pm & $4.05 * * *$ \\
\hline Packed cell volume & $\mathrm{L} / \mathrm{L}$ & 0.46 & \pm & 0.02 & 0.36 & \pm & $0.02 * *$ \\
\hline $\mathrm{MCV}$ & $\mathrm{fL}$ & 45.55 & \pm & 3.21 & 54.89 & \pm & $3.75^{*}$ \\
\hline $\mathrm{MCHC}$ & $g / L$ & 367.30 & \pm & 8.05 & 339.10 & \pm & $10.39 *$ \\
\hline White blood cells & $\times 10^{9} / \mathrm{L}$ & 7.21 & \pm & 0.58 & 12.69 & \pm & $0.95 * *$ \\
\hline Neutrophils & $\times 10^{3} / \mu \mathrm{L}$ & 0.66 & \pm & 0.05 & 0.76 & \pm & 0.06 \\
\hline Lymphocytes & $\times 10^{3} / \mu \mathrm{L}$ & 10.37 & \pm & 0.60 & 15.76 & \pm & $1.03 * *$ \\
\hline Monocytes & $\times 10^{3} / \mu \mathrm{L}$ & 0.15 & \pm & 0.01 & 0.43 & \pm & $0.02 * * *$ \\
\hline Eosinophils & $\times 10^{3} / \mu \mathrm{L}$ & 0.15 & \pm & 0.01 & 0.24 & \pm & $0.03 * *$ \\
\hline Basophils & $\times 10^{3} / \mu \mathrm{L}$ & 0.02 & \pm & 0.01 & 0.07 & \pm & $0.01 * *$ \\
\hline Thrombocytes & $\times 10^{9} / \mathrm{L}$ & 795.30 & \pm & 11.70 & 730.40 & \pm & $33.33^{*}$ \\
\hline Plasma protein & $\mathrm{g} / \mathrm{L}$ & 70.00 & \pm & 7.94 & 63.33 & \pm & 4.16 \\
\hline I.I & unit & 2.00 & \pm & 0.00 & 2.00 & \pm & 0.00 \\
\hline
\end{tabular}

$n=3$ rats per group

*Significant $(p<0.05)$; **significant $(p<0.01)$; ***significant $(p<0.001)$ 

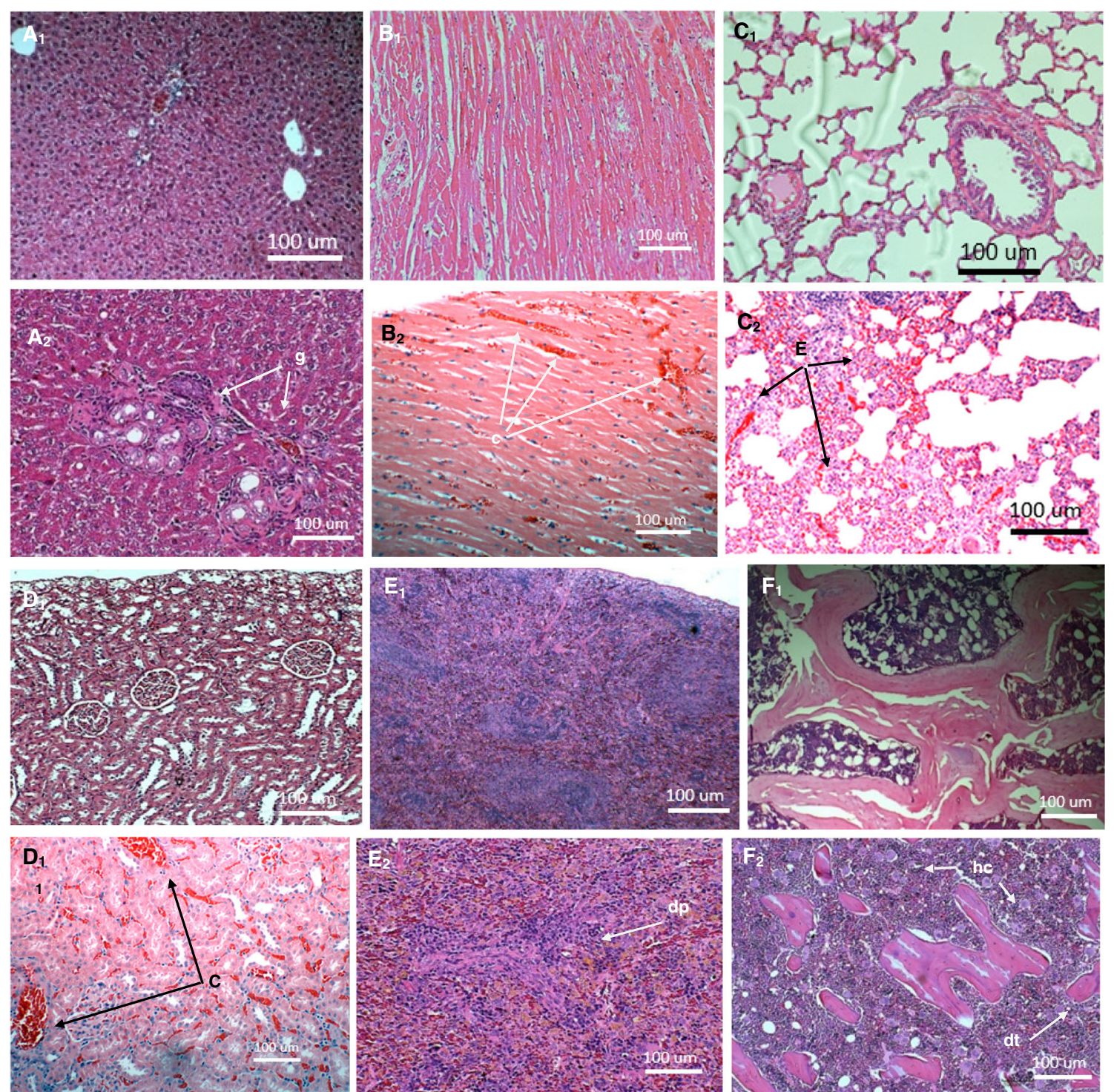

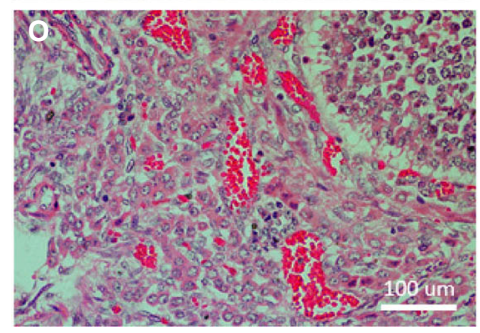

Fig. 5 Micrographs of the normal and pathological liver (a), heart (b), lungs (c), kidney (d), spleen (e) and bone (f) of SD rats from 14-day acute toxicity of subcutaneous injections of $29,500 \mathrm{mg} / \mathrm{m}^{2}$ ANC. Subscript 1 denotes normal tissues organ while subscript 2 denotes pathological tissues. Note the granular formation $(g)$ of the liver tissue; congested tissues; polymorphonuclear (PMN) cells infiltration (inflammation) and epithelialization of alveolar $(E)$ septae of the lung tissue; and depleted white pulp $(d p)$ of the splenic tissue and hypercellularity $(h c)$ and trabecular degeneration $(d t)$ of the bone tissue. The ovarian tissue $(O)$ was observed to be normal 


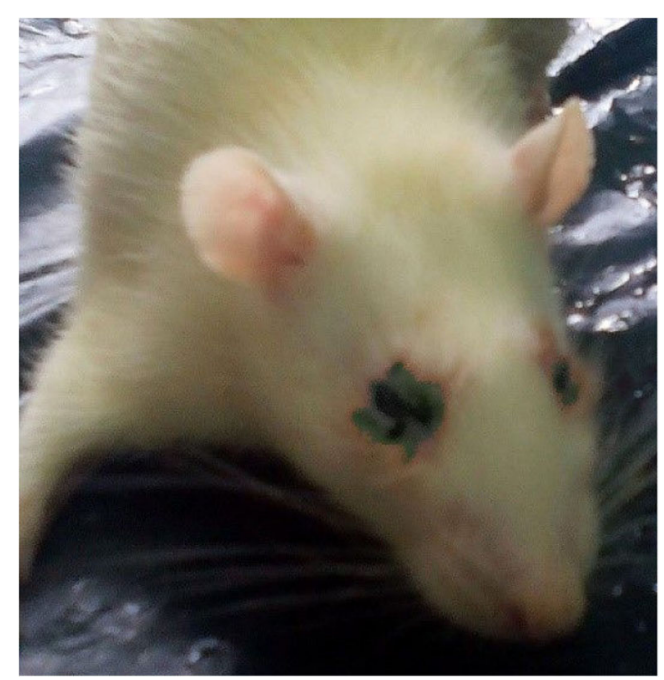

Fig. 6 A SD rat from the repeated dose 28-day trial of ANC. Note the necrosis halo around the eye

renal tubules. There was mild trabecular destruction and normal cortical thickness in the proximal tibial extremity. The lungs, the heart and the gonads showed no significant lesion.

\section{Discussion}

Physicochemical characterization of NPs has been identified as the first step towards meaningful understanding of its in vitro or in vivo biological data or interlaboratory comparison (McNeil 2011). Detailed physicochemical characterization and cytocompatibility of ANC had earlier been determined (Jaji et al. 2017).

Cockle shells are remarkable sources of naturally purified aragonite polymorphs of calcium carbonate (Islam 2012). Though calcium carbonate is renowned for its multifaceted applicability in fields of science (Epple 2003; Manolova et al. 2008; Colfen and Mann 2003; McLeod et al. 2004; Yu et al. 2006; Naka et al. 2006; Islam et al. 2011), it is poised for greater advancements in nanomedicine. Nanomedicine offers many prospects and benefits to medical research by making pharmaceuticals more efficacious (McNeil 2011). The nanotechnological top-down method of synthesis of ANC from this natural reservoir holds huge benefits. It enables obtaining aragonite crystals in their natural forms while retain most of their special features (Islam et al. 2011, 2012). The method enabled synthesis of spherical ANC of $30 \pm 5 \mathrm{~nm}$ size, as determined by TEM and FESEM. Although, morphology, structure,
Table 3 Body weights ( $g$ ) of SD rats in repeated dose 28-day trial of cockle shell-derived aragonite calcium carbonate nanocrystals in $\mathrm{SD}$ rats $($ mean $\pm \mathrm{SD})$

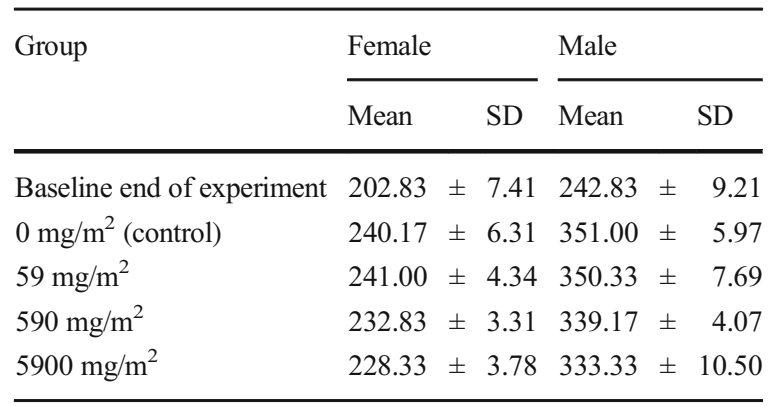

$n=6$ per group

size, surface area oil adsorption and chemical purity are important determinant factors for the use of calcium carbonate in varying applications, morphology appears to be the most important. As such, synthesis of calcium carbonate crystals with homogenous shape and size is now a topic of research due to the interesting mechanical and optical properties (Loy et al. 2004; Xu et al. 2006; Zhang et al. 2008; Zhanga et al. 2010).

The use of inorganic NPs as drug delivery carriers has gained wide concerns (Zhanga et al. 2010). Though, calcium carbonate NPs have shown promising potential for the development of carriers for drugs and are gaining recognitions as successful nanocarriers for subcutaneous delivery of biologicals (Ueno et al. 2004; He et al. 2008; Higaki et al. 2006; Zhang et al. 2012). There is paucity of research on their safe dosage for maximizing their therapeutic activity without harming biosystems (Zhang et al. 2012). This study demonstrates the safety of ANC as a potential agent for subcutaneous delivery of biologics and drugs. No mortality was recorded at the end of the acute and subchronic toxicity experiments. With a $\mathrm{LD}_{50}$ of $6450 \mathrm{mg} / \mathrm{kg}$ body weight (body weight), calcium carbonate has a wide margin of safety and low acute toxicity (Aguilar et al. 2011). There was no sign of toxicity from the initial dosages used in the acute toxicity experiment (single doses of 1770 and $11,800 \mathrm{mg}$ / $\left.\mathrm{m}^{2}\right)$. However, the final dosage $\left(29,500 \mathrm{mg} / \mathrm{m}^{2}\right)$ that was eventually used was for the 14-day acute toxicity study was associated with some toxic signs and lesions. The eventual recourse to high-dose usage was in line with the Organization for Economic Cooperation and Development (OECD) laid guidelines preliminary trial doses for acute toxicity studies, test number 423 (OECD 2010). 
Table 4 Ratios of body and organ weights ( $\mathrm{g}$ ) from repeated dose 28-day trial on cockle shell-derived aragonite calcium carbonate nanocrystals in $\mathrm{SD}$ rats (mean $\pm \mathrm{SD})$

\begin{tabular}{|c|c|c|c|c|c|c|c|c|c|c|c|c|}
\hline Organ & $0 \mathrm{mg} / \mathrm{m}^{2}$ (control). & & SD & $59 \mathrm{mg} / \mathrm{m}^{2}$ & & $\mathrm{SD}$ & $590 \mathrm{mg} / \mathrm{m}^{2}$ & & $\mathrm{SD}$ & $5900 \mathrm{mg} / \mathrm{m}^{2}$ & & SD \\
\hline \multicolumn{13}{|l|}{ Female } \\
\hline Body weights & 240.17 & \pm & 6.31 & 241.00 & \pm & 4.3 & 232.83 & \pm & 3.31 & 228.33 & \pm & 3.78 \\
\hline Liver & 10.54 & \pm & 0.58 & 10.20 & \pm & 0.77 & 10.06 & \pm & 1.12 & 12.14 & \pm & 3.36 \\
\hline Spleen & 0.85 & \pm & 0.05 & 1.02 & \pm & 0.04 & 1.15 & \pm & 0.47 & 1.70 & \pm & 1.01 \\
\hline Heart & 1.04 & \pm & 0.04 & 1.02 & \pm & 0.05 & 1.01 & \pm & 0.05 & 1.05 & \pm & 0.08 \\
\hline Lungs & 2.83 & \pm & 0.98 & 2.33 & \pm & 0.52 & 2.00 & \pm & 0.63 & 2.50 & \pm & 0.55 \\
\hline \multicolumn{13}{|l|}{ Kidney } \\
\hline Left & 1.05 & \pm & 0.08 & 1.03 & \pm & 0.07 & 1.02 & \pm & 0.13 & 1.18 & \pm & 0.40 \\
\hline Right & 1.02 & \pm & 0.04 & 1.00 & \pm & 0.00 & 1.01 & \pm & 0.07 & 1.19 & \pm & 0.40 \\
\hline \multicolumn{13}{|l|}{ Male } \\
\hline Body weight & 351.00 & \pm & 5.97 & 350.33 & \pm & 7.69 & 339.17 & \pm & 4.07 & 333.33 & \pm & 10.5 \\
\hline Liver & 12.17 & \pm & 1.33 & 12.72 & \pm & 2.57 & 14.51 & \pm & 1.37 & 14.93 & \pm & 2.07 \\
\hline Spleen & 1.07 & \pm & 0.13 & 0.95 & \pm & 0.20 & 1.25 & \pm & 0.24 & 2.17 & \pm & $0.67 * *$ \\
\hline Heart & 1.03 & \pm & 0.07 & 1.09 & \pm & 0.10 & 1.21 & \pm & 0.15 & 1.59 & \pm & 0.51 \\
\hline Lungs & 2.50 & \pm & 0.56 & 3.02 & \pm & 0.76 & 3.23 & \pm & 1.12 & 3.98 & \pm & $0.75 *$ \\
\hline \multicolumn{13}{|l|}{ Kidney } \\
\hline Left & 1.54 & \pm & 0.54 & 1.53 & \pm & 0.36 & 1.80 & \pm & 0.50 & 2.06 & \pm & 0.15 \\
\hline Right & 1.32 & \pm & 0.37 & 1.64 & \pm & 0.40 & 1.62 & \pm & 0.46 & 1.97 & \pm & 0.33 \\
\hline
\end{tabular}

$n=6$ per group

*Significant $(p<0.05) ; *$ significant $(p<0.01)$

Moderate histopathological lesions were observed in rats of the 14-day acute toxicity group. To the best of the knowledge of the authors of this recent study, no record is available detailing the toxicity of subcutaneous administration of calcium carbonate. Available data on calcium carbonate toxicity are related to mild to moderate oral toxicity from its usage as mineral supplement. This may not be unconnected to the fact that calcium carbonate from oral route dissociates into its constituent ions in the acid milieu of the stomach. Some of the component calcium is absorbed, via active transport or passive diffusion (Aguilar et al. 2011), while the greater percentage of the unabsorbed calcium is complexed to bile acids, free fatty acids and oxalic acid and excreted with the faeces (Heaney 2002). More so, most of the available toxicological data on calcium carbonate were on the micron, other than the nano sized. Toxicological findings have revealed high toxicity of NPs compared to micron sized particles of the same composition, thus, posing questions on their human health importance (Karlsson et al. 2009).

There was marked splenomegaly and hepatomegaly in the high toxicity group of both sexes. The hepatomegaly was also associated with fatty degeneration (lipidosis). Lu et al. (2010) reported mild splenomegaly and hepatomegaly associated with mesoporous silica NPs for cancer therapy in mice. In a study on 7day acute toxicity of single oral dose, $11,770 \mathrm{mg} / \mathrm{m}^{2}$ gavage of nano versus micron calcium carbonate and $261 \mathrm{U}$ vitamin D3/kg body weight in mice, no mortality or changes related to treatment were recorded in either group (Huang et al. 2009). Similarly, an acute toxicity study recorded no treatment-related effects in female Sprague-Dawley rats administered a single dose of $2000 \mathrm{mg}$ calcium carbonate/kg body weight by gavage (SafePharma 2008).

Though calcium carbonate does not meet the criteria for classification as dangerous substances according to Directive 67/548/EEC as amended on eye irritation due to topical calcium carbonate (CCA 2005), the present study recorded necrotizing lesion around the eyelids of rats from the high toxicity group following the 28-day subchronic toxicity study. This could be due to the systemic effect of ANC following the subcutaneous route of administration. Dendritic cells are the first line of contact following subcutaneous administration of 
Table 5 Blood results of female SD rats in the repeated dose 28-day trial of subcutaneous injection of ANC $(m e a n \pm S D)$

\begin{tabular}{|c|c|c|c|c|c|c|c|c|c|c|c|c|c|}
\hline Parameter & Unit & $0 \mathrm{mg} / \mathrm{m}^{2}$ (control) & & $\mathrm{SD}$ & $59 \mathrm{mg} / \mathrm{m}^{2}$ & & $\mathrm{SD}$ & $590 \mathrm{mg} / \mathrm{m}^{2}$ & & $\mathrm{SD}$ & $5900 \mathrm{mg} / \mathrm{m}^{2}$ & & $\mathrm{SD}$ \\
\hline Calcium & $\mathrm{mmol} / \mathrm{L}$ & 2.75 & \pm & 0.05 & 2.76 & \pm & 0.14 & 2.41 & \pm & $0.13 * * *$ & 2.45 & \pm & $0.08 * * *$ \\
\hline Alanine aminotransferase & $\mathrm{U} / \mathrm{L}$ & 22.55 & \pm & 3.22 & 28.16 & \pm & 7.90 & 40.98 & \pm & $5.12 * * *$ & 45.24 & \pm & $7.16^{* * *}$ \\
\hline Alkaline phosphatase & $\mathrm{U} / \mathrm{L}$ & 172.11 & \pm & 16.04 & 184.33 & \pm & 16.00 & 449.22 & \pm & $18.37 * * *$ & 659.33 & \pm & $18.11 * * *$ \\
\hline Aspartate aminotransferase & $\mathrm{U} / \mathrm{L}$ & 55.82 & \pm & 1.57 & 54.95 & \pm & 2.85 & 73.54 & \pm & $4.34 * * *$ & 132.35 & \pm & $9.21 * * *$ \\
\hline Creatine kinase & IU & 264.07 & \pm & 21.76 & 266.17 & \pm & 38.00 & 311.55 & \pm & 40.22 & 321.34 & \pm & 47.02 \\
\hline Creatinine & umol/L & 33.67 & \pm & 3.45 & 32.52 & \pm & 5.12 & 49.56 & \pm & $4.93 * * *$ & 65.66 & \pm & $2.79 * * *$ \\
\hline Phosphate & $\mathrm{mmol} / \mathrm{L}$ & 2.36 & \pm & 0.21 & 2.54 & \pm & 0.17 & 2.55 & \pm & 0.22 & 2.57 & \pm & 0.38 \\
\hline Urea & $\mathrm{mmol} / \mathrm{L}$ & 13.98 & \pm & 0.88 & 12.83 & \pm & 0.71 & 16.12 & \pm & $1.62 * *$ & 27.61 & \pm & $0.55^{* * *}$ \\
\hline Total protein & $\mathrm{g} / \mathrm{L}$ & 61.30 & \pm & 3.98 & 62.22 & \pm & 3.89 & 70.66 & \pm & $3.43 * *$ & 74.87 & \pm & $6.73^{* * *}$ \\
\hline Lactate dehydrogenase & $\mathrm{U} / \mathrm{L}$ & 307.33 & \pm & 37.29 & 359.28 & \pm & 50.82 & 341.23 & \pm & 36.73 & 337.52 & \pm & 22.39 \\
\hline Red blood cells & $\times 10^{12} / \mathrm{L}$ & 8.29 & \pm & 0.36 & 8.56 & \pm & 0.63 & 7.21 & \pm & $0.35^{*}$ & 6.49 & \pm & $0.85^{* * *}$ \\
\hline Haemoglobin & $\mathrm{g} / \mathrm{L}$ & 151.3 & \pm & 7.45 & 154.87 & \pm & 5.84 & 140.15 & \pm & 9.70 & 139.66 & \pm & $5.66^{*}$ \\
\hline Haematocrit & $\mathrm{L} / \mathrm{L}$ & 0.47 & \pm & 0.03 & 0.44 & \pm & 0.09 & 0.37 & \pm & $0.02 *$ & 0.36 & \pm & $0.05^{*}$ \\
\hline $\mathrm{MCV}$ & $\mathrm{fL}$ & 56.17 & \pm & 1.33 & 55.03 & \pm & 1.00 & 55.06 & \pm & 1.27 & 57.06 & \pm & 3.00 \\
\hline $\mathrm{MCHC}$ & $\mathrm{g} / \mathrm{L}$ & 355.78 & \pm & 3.32 & 362.03 & \pm & 21.09 & 329 & \pm & $2.76^{*}$ & 315.89 & \pm & $19.00 * * *$ \\
\hline White blood cells & $\times 10^{9} / \mathrm{L}$ & 5.22 & \pm & 0.48 & 6.37 & \pm & 4.36 & 8.97 & \pm & 1.08 & 14.68 & \pm & 1.24 \\
\hline Neutrophils & $\times 10^{3} / \mu \mathrm{L}$ & 0.70 & \pm & 0.04 & 0.68 & \pm & 0.03 & 0.73 & \pm & 0.03 & 0.78 & \pm & $0.02 * *$ \\
\hline Lymphocytes & $\times 10^{3} / \mu \mathrm{L}$ & 10.82 & \pm & 0.23 & 10.83 & \pm & 0.29 & 13.74 & \pm & $0.16^{* * * 0}$ & 15.67 & \pm & $0.35^{* * *}$ \\
\hline Monocytes & $\times 10^{3} / \mu \mathrm{L}$ & 0.14 & \pm & 0.02 & 0.17 & \pm & 0.03 & 0.19 & \pm & $0.02 *$ & 0.20 & \pm & $0.04 * *$ \\
\hline Eosinophils & $\times 10^{3} / \mu \mathrm{L}$ & 0.16 & \pm & 0.03 & 0.15 & \pm & 0.02 & $0.22 * *$ & \pm & 0.01 & 0.25 & \pm & $0.03^{* * *}$ \\
\hline Basophils & $\times 10^{3} / \mu \mathrm{L}$ & 0.00 & \pm & 0.00 & 0.00 & \pm & 0.00 & 0.00 & \pm & 0.00 & 0.00 & \pm & 0.00 \\
\hline Thrombocytes & $\times 10^{9} / \mathrm{L}$ & 594.81 & \pm & 17.13 & 582.13 & \pm & 21.61 & 439.66 & \pm & $14.80 * * *$ & 373.63 & \pm & $23.11^{* * * *}$ \\
\hline Plasma protein & $\mathrm{g} / \mathrm{L}$ & 77.00 & \pm & 2.07 & 76.17 & \pm & 2.76 & 74.02 & \pm & 3.88 & 60.83 & \pm & $12.67 * *$ \\
\hline
\end{tabular}

$n=6$ rats/group

$*$ Significant $(p<0.05) ; * *$ significant $(p<0.01) ; * * *$ significant $(p<0.001)$

immunogenic nanoparticle compounds; these cells engulf the foreign material based on its size and present to antigen presenting cells, which move to resident reticuloendothelial tissues such as the spleen, tonsils and lymph nodes through the lymphatic drainage systems. In the study, large particulate materials $(500-1000 \mathrm{~nm})$ were mostly found in DC at the injection site, while small $(20-200 \mathrm{~nm})$ were found in DC of close by lymph nodes (Manolova et al. 2008).

Most of the haematological parameters in the repeated dose 28-day trial groups showed no significant variations. The changes in haematological parameters recorded from this study are related to cascade of immunological responses caused by ANC. An earlier study by Harlan Laboratories (2010), on a combined repeat dose oral toxicity/reproduction/developmental toxicity screening study with "nano" calcium carbonate in Wistar rats (Han ${ }^{\mathrm{TM}} / \mathrm{HsdRccHan}{ }^{\mathrm{TM}} / \mathrm{WIST}$ strain), had documented minor haematological changes in males receiving $5900 \mathrm{mg} / \mathrm{m}^{2} /$ day. NPs have been associated with changes in haematological parameters (Smith et al. 2007; Xie et al. 2011; Khabbazi et al. 2015).

The severity of the histopathological lesions in the viscera and bones of the toxicity groups in both sexes were dosage dependent and not in agreement with earlier reports by Harlan Laboratories (2010) and Aguilar et al. (2011) that documented the absence of treatment-related effects from studies on oral administration of calcium carbonate. This was attributed to the difference in route of administration of calcium carbonate in both studies and size in the later study, as discussed above. The serious toxicity lesions were limited to the medium to high subcutaneous dose groups of ANC. The gonads and skin showed no significant lesion. It has been observed that apart from blood, phagocytosis and endocytosis of NPs by body cells have also been observed to play very important roles in their further spread to distant organs (Garnett and Kallinteri 2006; Yacobi et al. 2010; Greulich et al. 2011). Irrespective of natural barriers, low concentrations of NPs have 
Table 6 Blood results of male SD rats in the repeat dose 28-day trial of subcutaneous injection of ANC (Mean \pm SD)

\begin{tabular}{|c|c|c|c|c|c|c|c|c|c|c|c|c|c|}
\hline Parameter & Unit & $0 \mathrm{mg} / \mathrm{m}^{2}$ (control) & & $\mathrm{SD}$ & $59 \mathrm{mg} / \mathrm{m}^{2}$ & & $\mathrm{SD}$ & $590 \mathrm{mg} / \mathrm{m}^{2}$ & & $\mathrm{SD}$ & $5900 \mathrm{mg} / \mathrm{m}^{2}$ & & SD \\
\hline Calcium & $\mathrm{mmol} / \mathrm{L}$ & 2.91 & \pm & 0.19 & 2.90 & \pm & 0.06 & 2.59 & \pm & $0.14^{*}$ & 2.49 & \pm & $0.34 * *$ \\
\hline $\begin{array}{l}\text { Alanine } \\
\text { aminotransferase }\end{array}$ & $\mathrm{U} / \mathrm{L}$ & 21.48 & \pm & 8.90 & 24.20 & \pm & 4.07 & 33.68 & \pm & $3.71 *$ & 57.35 & \pm & $6.75^{* * * *}$ \\
\hline Alkaline phosphatase & $\mathrm{U} / \mathrm{L}$ & 275.00 & \pm & 24.73 & 289.50 & \pm & 20.03 & 381.17 & \pm & $19.71 * * *$ & 760.52 & \pm & $10.09 * * *$ \\
\hline $\begin{array}{l}\text { Aspartate } \\
\text { aminotransferase }\end{array}$ & $\mathrm{U} / \mathrm{L}$ & 56.20 & \pm & 6.43 & 64.85 & \pm & 7.33 & 74.28 & \pm & $6.18^{* *}$ & 133.73 & \pm & $9.10^{* * * *}$ \\
\hline Creatine kinase & $\mathrm{U} / \mathrm{L}$ & 324 & \pm & 52.24 & 326.67 & \pm & 37.74 & 368.67 & \pm & 47.57 & 377.17 & \pm & 20.00 \\
\hline Creatinine & $\mathrm{umol} / \mathrm{L}$ & 33.00 & \pm & 1.03 & 35.00 & \pm & 2.76 & 65.83 & \pm & $2.85^{* * *} *$ & 62.83 & \pm & $3.08 * * *$ \\
\hline Phosphate & $\mathrm{mmol} / \mathrm{L}$ & 2.40 & \pm & 0.28 & 2.35 & \pm & 0.10 & 2.74 & \pm & 0.20 & 2.75 & \pm & 0.4 \\
\hline Urea & $\mathrm{mmol} / \mathrm{L}$ & 14.90 & \pm & 0.90 & 14.18 & \pm & 0.72 & 18.93 & \pm & $0.92 * * *$ & 23.72 & \pm & $0.81 * * *$ \\
\hline Total protein & $\mathrm{g} / \mathrm{L}$ & 63.80 & \pm & 3.40 & 62.28 & \pm & 1.60 & 70.78 & \pm & $3.02 *$ & 71.75 & \pm & $6.12^{*}$ \\
\hline Lactate dehydrogenase & $\mathrm{U} / \mathrm{L}$ & 356.00 & \pm & 79.61 & 423.00 & \pm & 86.42 & 327.67 & \pm & 97.55 & 471.00 & \pm & 51.00 \\
\hline Red blood cells & $\times 10^{12} / \mathrm{L}$ & 8.89 & \pm & 0.44 & 8.85 & \pm & 0.49 & 7.84 & \pm & $0.86^{* *}$ & 7.65 & \pm & $0.38^{*}$ \\
\hline Haemoglobin & $\mathrm{g} / \mathrm{L}$ & 164.97 & \pm & 8.76 & 167.17 & \pm & 6.52 & 151.12 & \pm & $6.16^{* *}$ & 140.78 & \pm & $4.91 * * *$ \\
\hline Haematocrit & $\mathrm{L} / \mathrm{L}$ & 0.49 & \pm & 0.03 & 0.50 & \pm & 0.02 & 0.43 & \pm & 0.06 & 0.41 & \pm & $0.05^{*}$ \\
\hline $\mathrm{MCV}$ & $\mathrm{fL}$ & 56.91 & \pm & 1.76 & 56.82 & \pm & 2.41 & 52.98 & \pm & $1.47 *$ & 53.05 & \pm & $3.03 *$ \\
\hline $\mathrm{MCHC}$ & $\mathrm{g} / \mathrm{L}$ & 342.00 & \pm & 5.57 & 331.04 & \pm & 11.11 & 339.61 & \pm & $7.58^{*}$ & 314.94 & \pm & $5.10^{* * * *}$ \\
\hline White blood cells & $\times 10^{9} / \mathrm{L}$ & 13.31 & \pm & 0.73 & 14.17 & \pm & 1.13 & 15.25 & \pm & $1.12^{* *}$ & 17.35 & \pm & $0.26^{* * *}$ \\
\hline Neutrophils & $\times 10^{3} / \mu \mathrm{L}$ & 0.94 & \pm & 0.05 & 0.98 & \pm & 0.02 & 0.96 & \pm & 0.05 & 1.01 & \pm & 0.05 \\
\hline Lymphocytes & $\times 10^{3} / \mu \mathrm{L}$ & 10.73 & \pm & 0.51 & 10.81 & \pm & 0.45 & 11.78 & \pm & $0.64 *$ & 13.99 & \pm & $0.55^{* * * *}$ \\
\hline Monocytes & $\times 10^{3} / \mu \mathrm{L}$ & 0.23 & \pm & 0.05 & 0.22 & \pm & 0.03 & 0.32 & \pm & $0.02 * *$ & 0.44 & \pm & $0.06^{* * * *}$ \\
\hline Eosinophils & $\times 10^{3} / \mu \mathrm{L}$ & 0.12 & \pm & 0.00 & 0.13 & \pm & 0.01 & 0.17 & \pm & $0.01 * * *$ & 0.20 & \pm & $0.02 * * *$ \\
\hline Basophils & $\times 10^{3} / \mu \mathrm{L}$ & 0.00 & \pm & 0.00 & 0.00 & \pm & 0.00 & 0.00 & \pm & 0.00 & 0.00 & \pm & 0.00 \\
\hline Thrombocytes & $\times 10^{9} / \mathrm{L}$ & 1050.00 & \pm & 52.48 & 1041.83 & \pm & 46.92 & 944.33 & \pm & $39.24 * *$ & 834.65 & \pm & $27.99 * * *$ \\
\hline Plasma protein & $\mathrm{g} / \mathrm{L}$ & 72.11 & \pm & 2.42 & 70.19 & \pm & 1.79 & 73.57 & \pm & 2.17 & 74.33 & \pm & 3.28 \\
\hline
\end{tabular}

$n=6$ rats/group

*Significant $(p<0.05) ; * *$ significant $(p<0.01) ; * * *$ significant $(p<0.001)$

been found in the liver, the spleen, the heart and the brain (Ji et al. 2006; Oberdorster et al. 2002).

Fig. 7 Photographs of SD rats from control (a) and high toxicity $\left(5900 \mathrm{mg} / \mathrm{m}^{2}\right)$ (b) groups depicting a normal and a liver with abscess in $\mathbf{a}$ and $\mathbf{b}$, respectively. Note the centrally located circumscribed abscess (arrow) in the liver of rat from the high toxicity group (b)
ANC at low dosage is largely a safe inorganic crystal with potentials for subcutaneous delivery of biologicals

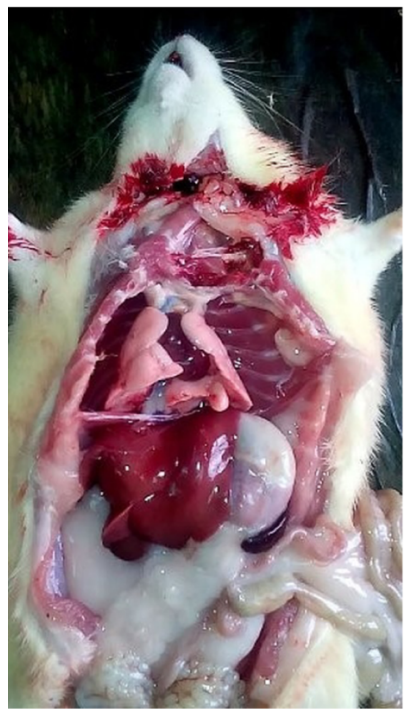

A

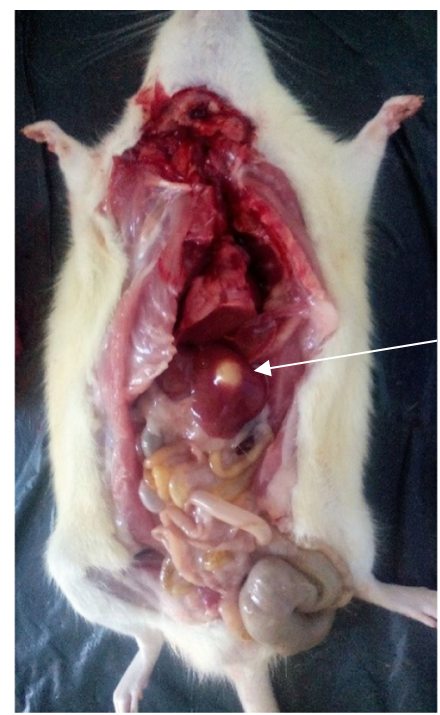

B 
High dosage group ( $1 \mathrm{~g} / \mathrm{kg}$ body weight)

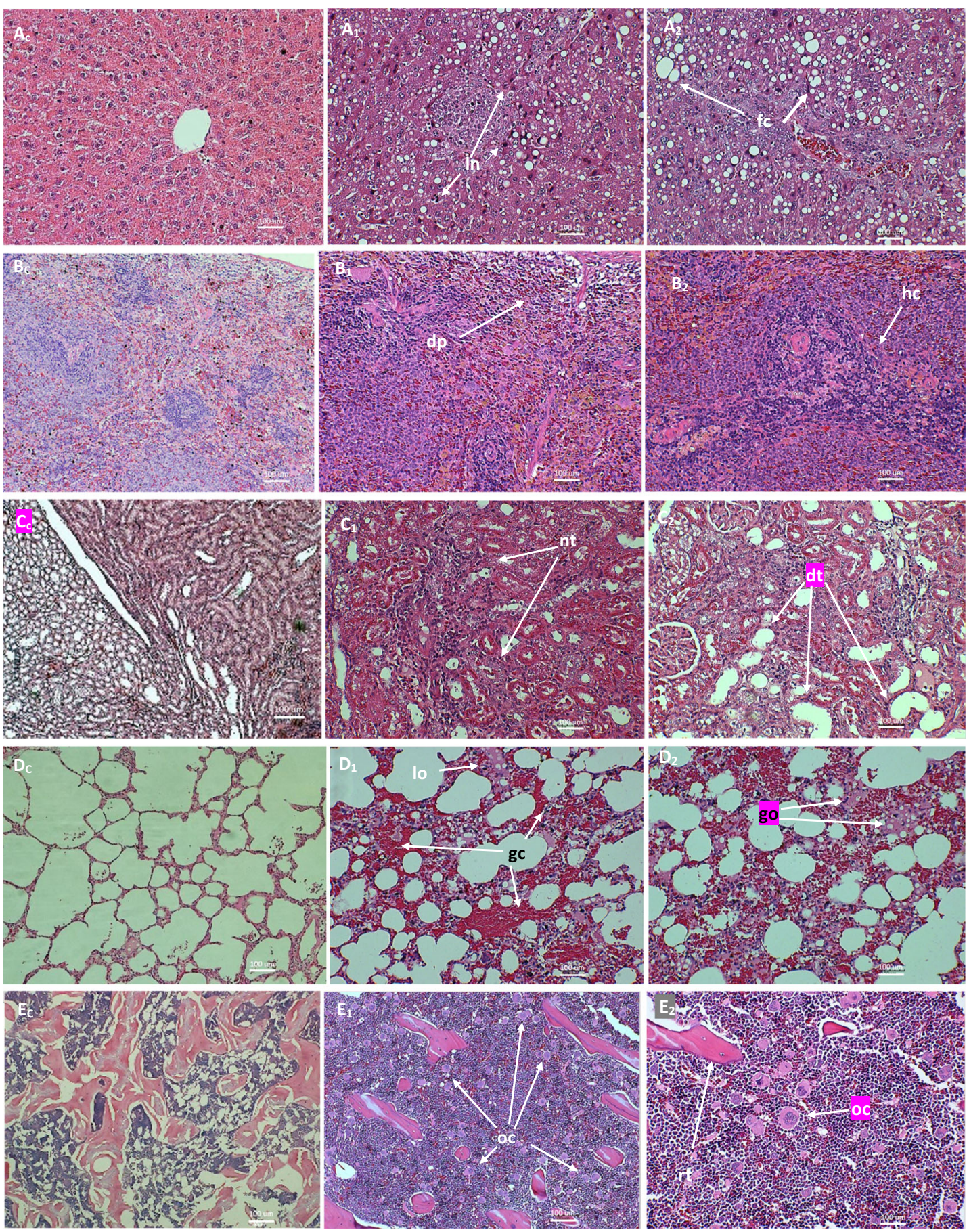

Fig. 8 Micrographs of the normal and pathological liver (a), spleen (b), kidney (c), lung (d) and bone (e) of SD rats from high dosage $\left(5900 \mathrm{mg} / \mathrm{m}^{2}\right)$ group of 28-day subchronic toxicity of subcutaneous ANC injections. Subscript $C$ denotes normal tissues while subscripts 1 and 2 denote pathological tissues. Note the multifoci necrosis ( $l n$, blackish) and marked fatty cells $(f c$, whitish) lodgement in the liver tissue; the depopulation of the white pulp $(d p)$ and hypercellularity $(h c)$ of the splenic tissue; the degenerations $(d t)$ and necrosis $(n t)$ of renal tubules with mild glomerular lesion; the generalized congestion $(g c)$ and oedema $(g o)$ of the lung tissue; and the marked increase in osteoclast population $(o c)$ and trabecular resorption $(r t)$ in the bone tissue 
Medium dosage group $(0.1 \mathrm{~g} / \mathrm{kg}$ body weight $)$
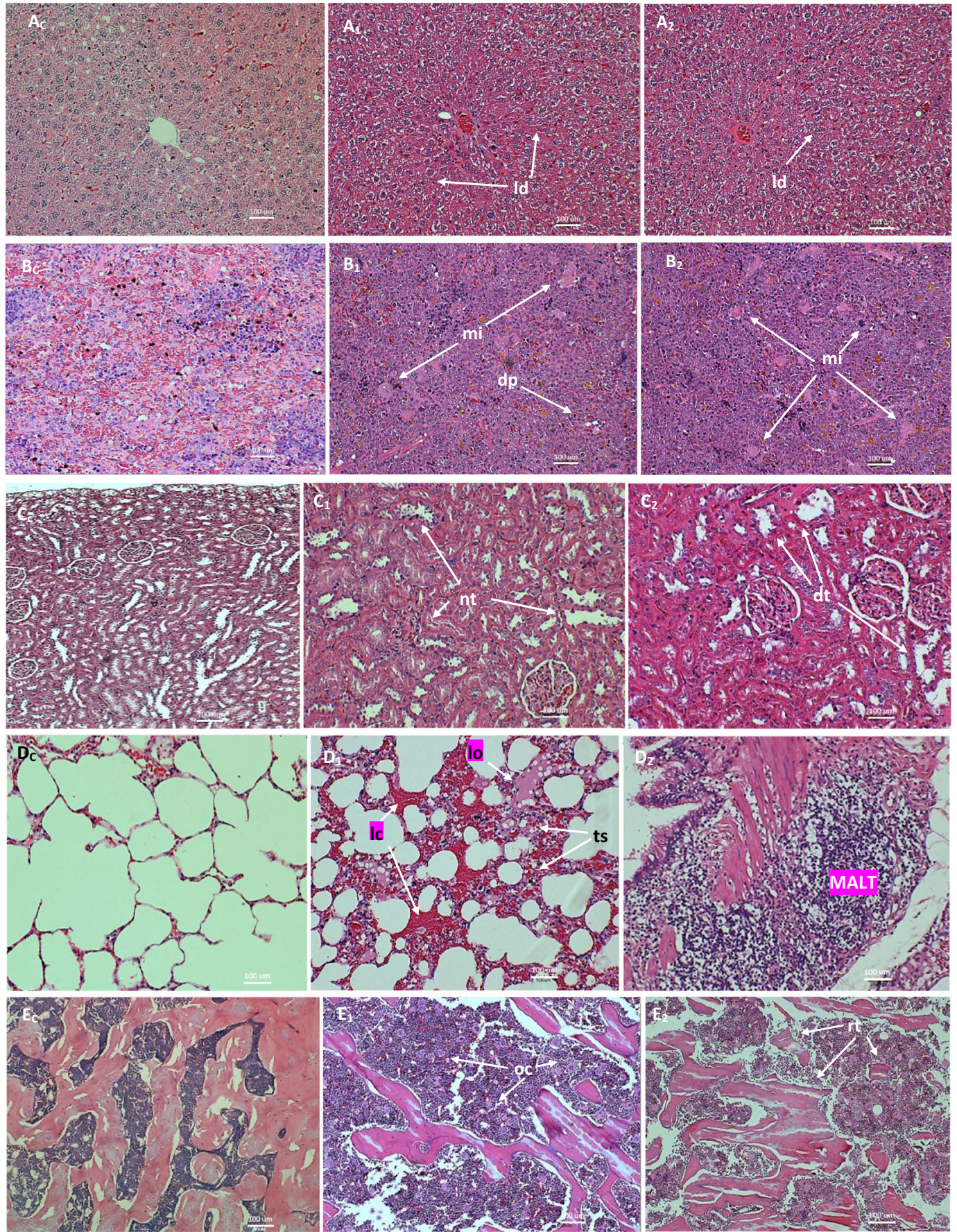

Fig. 9 Micrographs of the normal and pathological liver (a), spleen (b), kidney (c), lung (d) and bone (E) of SD rats from medium dosage $\left(590 \mathrm{mg} / \mathrm{m}^{2}\right)$ group of 28-day subchronic toxicity of subcutaneous ANC injections. Subscript $C$ denotes normal tissues while subscripts 1 and 2 denote pathological tissues. Note the mild lobar degenerations without necrosis $(l d)$ in the liver tissue; the macrophage infiltration ( $m i)$ and depletion of white pulp $(d p)$ areas in the splenic tissue; the mild glomerular and tubular degeneration $(d t)$ and necrosis in tubules $(n t)$ of the kidney tissue; the congestion $(l c)$, oedema (lo), thickened alveolar septae $(t s)$ and the mild proliferation of mucosa-associated lymphoid tissue (MALT) cells in the lung tissue; and the moderate increase in osteoclast population and trabecular resorption in the bone tissue 
Low dosage group $(0.01 \mathrm{~g} / \mathrm{kg}$ body weight $)$
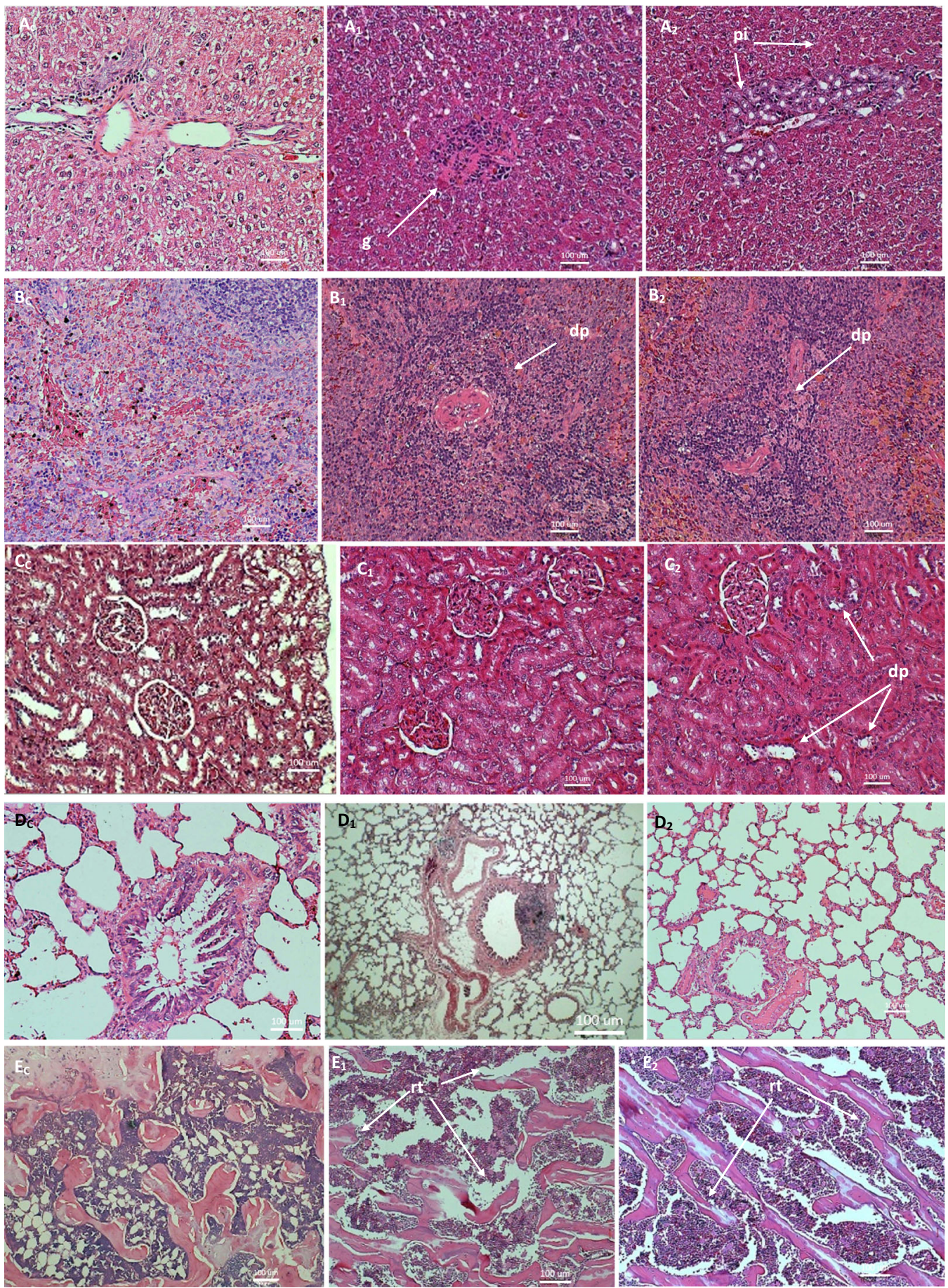

Fig. 10 Micrographs of the normal and pathological liver (a), spleen (b), kidney (c), lung (d) and bone (e) of SD rats from low dosage $\left(59 \mathrm{mg} / \mathrm{m}^{2}\right)$ group of 28-day subchronic toxicity of subcutaneous ANC injections. Subscript $C$ denotes normal tissues organ while subscripts 1 and 2 denote pathological tissues. Note the granular $(g)$ formation and periportal infiltration ( $p i)$ in the liver tissue; mild depletion of white pulp $(d p)$ in the splenic tissue; the reversible degenerations without necrosis of renal tubules $(d t)$; and the mild trabecular destruction $(r t)$ in the bone tissue. The lung tissues show no significant lesion 
and drugs, as well as a calcium carbonate supplement. The low dosage ( $59 \mathrm{mg} / \mathrm{m}^{2}$ body weight) group showed the high safety margin of ANC. The study was able to correct the impression that $\mathrm{CaCO}_{3}$ is generally safe. The safety of $\mathrm{CaCO}_{3}$ nanocrystals in vivo is dependent on its concentration and route of administration.

Acknowledgements The authors of this study wish to express their appreciations to the staff of Laboratories of Pharmacology and Histopathology, Universiti Putra Malaysia, Malaysia, for their technical assistance.

Compliance with ethical standards The protocols for these studies were approved by the Institutional Animal Care and Use Committee (IACUC), Universiti Putra Malaysia (AUP number R002/2014).

Conflict of interest The authors declare that they have no conflict of interest.

Open Access This article is distributed under the terms of the Creative Commons Attribution 4.0 International License (http:// creativecommons.org/licenses/by/4.0/), which permits unrestricted use, distribution, and reproduction in any medium, provided you give appropriate credit to the original author(s) and the source, provide a link to the Creative Commons license, and indicate if changes were made.

\section{References}

Aguilar F, Dusemund B, Galtier P, Gilbert J, Gott DM, Grilli S, Gürtler R, König J, Lambré C, Larsen J-C, Leblanc J-C, Mortensen A, Parent-Massin D, Pratt I, Rietjens IMCM, Stankovic I, Tobback P, Verguieva T, Woutersen RA (2011) Scientific opinion on re-evaluation of calcium carbonate $(E$ 170) as a food additive. European Food Safety Authority (EFSA) Journal 9(7):231854 http://www.efsa.europa. eu/sites/default/files/scientific_output/files/main documents/2318.pdf

Awang-Hazmi AJ, Zuki ABZ, Noordin MM, Jalila A, Norimah Y (2007) Mineral composition of the cockle (Anadara granosa) shells of west coast of peninsular Malaysia and it's potential as biomaterial for use in bone repair. J Anim Vet Adv 6(5): 591-597 http://medwelljournals.com/abstract/?doi= javaa.2007.591.594

Borm PJ, Robbins D, Haubold S, Kuhlbusch T, Fissan H, Donaldson K, Schins R, Stone V, Kreyling W, Lademann J, Krutmann J, Warheit D, Oberdorster E (2006) The potential risks of nanomaterials: a review carried out for ECETOC. Part Fibre Toxicol 3(11):1-35. doi:10.1186/1743-8977-3-11 http://www.particleandfibretoxicology.com/content/3/1/11

CCA (Calcium Carbonate Association) (2005) Skin \& eye irritation studies performed on calcium carbonate, Summary report, December 2005, Calcium Carbonate Association-
Europe A.I.S.B.L. Member of IMA-Europe, p 1-2. http://www.cca-europe.eu/fileadmin/cca/CCA_new/CCA Summary_report_final_.pdf

Colfen H, Mann S (2003) Review: higher-order organization by mesoscale self-assembly and transformation of hybrid nanostructures. Angew Chem Int Ed 42(21):2319-2431

Colvin VL (2003) The potential environmental impact of engineered nanomaterials. Nat Biotechnol 21:1166-1170

Combes C, Miao B, Bareille R, Rey C (2006) Preparation, physical-chemical characterisation and cytocompatibility of calcium carbonate cements. Biomaterials 27:1945-1945

Drobne D (2007) Nanotoxicology for safe nanotechnology. Arh Hig Rada Toksikol 58:471-478. doi:10.2478/v10004-0070040-4

Elsaesser A, Howard CV (2012) Toxicology of nanoparticles. Adv Drug Deliv Rev 64:129-137

Epple M (2003) Book review: biomineralization principles and concepts in bioinorganic materials chemistry. By Stephen Mann. Angew Chem Int Ed 42:381-382. doi:10.1002 /anie. 200390143

Garnett MC, Kallinteri P (2006) Nanomedicines and nanotoxicology: some physiological principles. Occup Med (Lond) 56:307-311

Greulich C, Diendorf J, Simon T, Eggeler G, Epple M, Koller M (2011) Uptake and intracellular distribution of silver nanoparticles in human mesenchymal stem cells. Acta Biomater 7: 347-354

Guo F, Li Y, Xu H, Zhao G, He X (2007) Size-controllable synthesis of calcium carbonate nanoparticles using aqueous foam films as templates. Mater Lett 61(27):4937-4939

Gwinn MR, Vallyathan V (2006) Nanoparticles: health effects prospects and constraints. Environ Health Perspectives 114: $1818-1825$

Harlan Laboratories (2010) Calcium carbonate (nano): oral gavage combined repeat dose toxicity study with reproduction/ developmental toxicity screening test in the rat. Project number: 2974/0010. Unpublished study report provided by CCAEurope. May 2011

He XW, Liu T, Chen YX, Cheng DJ, Li XR, Xiao Y et al (2008) Calcium carbonate nanoparticle delivering vascular endothelial growth factor-C siRNA effectively inhibits lymphangiogenesis and growth of gastric cancer in vivo. Cancer Gene Ther 15(3):193-202. doi:10.1038/sj. cgt. 7701122

Heaney RP (2002) Ethnicity, bone status, and calcium requirement. Nutr Res 22(1-2):153-178. doi:10.1016/S0271-5317 (01)00358-X

Higaki M, Kameyama M, Udagawa M, Ueno Y, Yamaguchi Y, Igarashi R, Ishihara T, Mizushima Y (2006) Transdermal delivery of calcium carbonate-nanoparticles containing insulin. Diabetes Technology and Therapeutics 8(3):369-374. doi:10.1089/dia.2006.8.369-374

Hodgson E (2010) A textbook of modern toxicology, 4th edn. Wiley, Hoboken ISBN 978-0-470-46206-5 (cloth)

Hoque ME, Shehryar M, Islam KMN (2013) Processing and characterization of cockle shell calcium carbonate (CaCO3) bioceramic for potential application in bone tissue Engineering. Journal of Material Science and Engineering 2(4):1000132 
Hristozov D, Malsch I (2009) Hazards and risks of engineered nanoparticles for the environment and human health. Sustainability 1:1161-1194. doi:10.3390/su1041161

Huang S, Chen JC, Hsu CW, Chang WH (2009) Effects of nano calcium carbonate and nano calcium citrate on toxicity in ICR mice and on bone mineral density in an ovariectomized mice model. Nanotechnology 20(37):375102

Islam KN, Bakar MZBA, Noordin MM, Hussein MZB, Rahman NSBA, Ali ME (2011) Characterisation of calcium carbonate and its polymorphs from cockle shells (Anadara granosa). Powder Technol 213(1):188-191

Islam, KN, Zuki, ABZ Ali ME, Bin Hussein, MZ, Noordin, MM Loqman, MY Wahid, H, MA Hakim and Abd Hamid, SB (2012) Facile Synthesis of Calcium Carbonate Nanoparticles from Cockle Shells. Hindawi Publishing Corporation. Journal of Nanomaterials 2012:5. doi:10.1155/2012/534010

ISO/TS (International Organisation for Standardization/Technica Specification) (2015) Nanotechnologies-vocabulary-part 2: nano -objects. ISO/TC 229, 1, 2015-06, 01.040.07, 07.030. (C) 2015 ISO

Jaji AZ, Bakar MZBA, Mahmud R, Loqman MY, Hezmee MNM, Isa T, Wenliang F, Hammadi NI (2017) Synthesis, characterization, and cytocompatibility of potential cockle shell aragonite nanocrystals for osteoporosis therapy and hormonal delivery. Nanotechnol Sci Appl 10:23-33

Ji ZQ, Sun H, Wang H, Xie Q, Liu Y, Wang Z (2006) Biodistribution and tumor uptake of $\mathrm{C} 60(\mathrm{OH}) \mathrm{x}$ in mice. $\mathrm{J}$ Nanopart Res 8:53-63

Karlsson HL, Gustafsson J, Cronholm P, Möller L (2009) Sizedependent toxicity of metal oxide particles - a comparison between nano- and micrometer size. Toxicol Lett 188(2): 112-118. doi:10.1016/j.toxlet.2009.03.014

Khabbazi M, Harsij M, Hedayati AK, Gholipoor H, Gerami MH, Ghafari FH (2015) Effect of $\mathrm{CuO}$ nanoparticles on some hematological indices of rainbow trout Oncorhynchus mykiss and their potential toxicity. Nanomed J 2(1):67-73. doi:10.7508/nmj.2015.01.008

Kitano H (2002) Computational systems biology. Nature 420: 206-210. doi:10.1038/nature01254

Kroll A, Pillukat MH, Hahn D, Schnekenburger J (2012) Interference of engineered nanoparticles with in vitro toxicity assays. Arch Toxicol 86:1123-1136. doi:10.1007/s00204012-0837-z

Loy JE, Guo JH, Severtson SJ (2004) Role of adsorption fractionation in determining the calcium carbonate scale inhibition performance of polydisperse sodium polyacrylate. Ind Eng Chem Res 43:1882-1887

Lu J, Liong M, Li Z, Zink J, Tamanoi E (2010) Biocompatibility, biodistribution, and drug-delivery efficiency of mesoporous silica nanoparticles for cancer therapy in animals. Small 6(16):1794-1805. doi:10.1002/smll.201000538

Manolova V, Flace A, Bauer M, Schwarz K, Saudan P, Bachmann MF (2008) Nanoparticles target distinct dendritic cell populations according to their size. Eur J Immunol 38(5):14041413

McLeod MC, Gale WF, Roberts CB (2004) Metallic nanoparticle production utilizing a supercritical carbon dioxide flow process. Langmuir 20(17):7078-7082

McNeil SE (2011) Characterization of nanoparticles intended for drug delivery. Methods Mol Biol 697:269. Humana Press. ISBN 1607619083, 9781607619086 DOI 10.1007/978-1-
60327-198-1_1, C Springer Science+Business Media, LLC 2011

Moorthi C, Manavalan R, Kathiresan K (2011) Nanotherapeutics to overcome conventional cancer chemotherapy limitations. Journal of Pharm Pharmaceutical Sciences 14:67-77

Morose G (2010) The 5 principles of "design for safer nanotechnology". Journal of Clean Production 18:285-289

Muhammad SI, Ismail M, Mahmud R, Esmaile MF, Zuki ABZ (2013) Bone mass density estimation: Archimede's principle versus automatic $\mathrm{x}$-ray histogram and edge detection technique in ovariectomized rats treated with germinated brown rice bioactives. Clin Interv Aging 8:1421-1431. doi:10.2147/CIA.S49704 ISSN 1176-9092; ESSN: 11781998

Naka K, Huang SC, Chujo Y (2006) Formation of stable vaterite with poly(acrylic acid) by the delayed addition method. Langmuir 22:7760-7767

Nel A, Xia T, Madler L, Li N (2006) Toxic potential of materials at the nanolevel. Science 311:622-627

Oberdorster G, Sharp Z, Atudorei V, Elder A, Gelein R, Lunts A, Kreyling W, Cox C (2002) Extrapulmonary translocation of ultrafine carbon particles following whole-body inhalation exposure of rats. Journal of Toxicological Environment Health A 65:1531-1543

Oberdorster G, Oberdorster E, Oberdorster J (2005) Nanotoxicology: an emerging discipline evolving from studies of ultrafine particles. Environ Health Perspect 113:823839

OECD (Organisation for Economic Co-operation and Development) (2010) OECD Stat, (data base). doi:10.1787 /data-00285-en. Accessed 15 Mar 2016

SafePharma Laboratories, (2008). Calcium carbonate: acute oral toxicity in the rat-fixed dose method. SPL Project Number 1992/0009. Unpublished study report provided by CCAEurope.April 2011.

Sayes, C.M. and Warheit, D.B. (2009). Characterization of nanomaterials for toxicity assessment, Wiley Interdiscip. Rev. Nanomed. Nanobiotechnol. 1 (2009) 660-670.

Smith CJ, Shaw BJ, Handy RD (2007) Toxicity of single walled carbon nanotubes to rainbow trout, (Oncorhynchus mykiss): respiratory toxicity, organ pathologies, and other physiological effects. Aquat Toxicol 82:94-109. doi:10.1016/j. aquatox.2007.02.003

Stern ST, McNeil SE (2008) Nanotechnology safety concerns revisited. Toxicol Sci 101:4-21

The Royal Society (2004) Nanoscience and nanotechnologies: opportunities and uncertainties. The Royal Society \& the Royal Academy of Engineering. ISBN 0854036040. Available at http://www.nanotec.org.uk/finalReport.htm. Accessed 2 Feb 2016

Ueno Y, Futagawa H, Takagi Y, Ueno A, Mizushima Y (2004) Drug-incorporating calcium carbonate nanoparticles for a new delivery system. Journal of Controlled Release, 2005 103(1):93-98

Wang L, Sondi I, Matijevic' E (1999) Preparation of uniform needle-like aragonite particles by homogeneous precipitation. Journal of Colloid Interface Sciience 218:545

Wang C, Zhao J, Zhao X, Bala H, Wang Z (2006) Synthesis of nanosized calcium carbonate (aragonite) via a polyacrylamide inducing process. Powder Technol 163(3):134-138 
Xie S, Wang F, Wang Y, Zhu L, Dong Z, Wang X, Li X, Zhou W (2011) Acute toxicity study of tilmicosin-loaded hydrogenated castor oil-solid lipid nanoparticles. Part Fibre Toxicol 8: 33. doi:10.1186/1743-8977-8-33

Xu AW, Antonietti M, Colfen H, Fang YP (2006) Uniform hexagonal plates of vaterite calcium carbonate mesocrystals formed by biomimetic mineralization. Adv Funct Mater 16: 903

Yacobi NR, Malmstadt N, Fazlollahi F, DeMaio L, Marchelletta R, Hamm-Alvarez SF, Borok Z, Kim KJ, Crandall ED (2010) Mechanisms of alveolar epithelial translocation of a defined population of nanoparticles. Am J Respir Cell Mol Biol 42: 604-614

Yu, J. Guo, H., Davis, S. A., and Mann, S. (2006). "Fabrication of hollow inorganic microspheres by chemically induced self- transformation," Adv Funct Mater, vol. 16, no. 15, pp. 20352041, 2006.

Zhang JC, Zhang J, Feng X, Li W, Zhao Y, Han B (2008) Influence of surfactant on themorphologies of $\mathrm{CaCO} 3$ by carbonation route with compressed CO2. Colloid Surface A 324(1-3):167-170

Zhang X, Sun M, Zheng A, Cao D, Bi Y, Sun J (2012) Preparation and characterization of insulin-loaded bioadhesive PLGA nanoparticles for oral administration. Eur J Pharm Sci 45(5):632-638. doi:10.1016/j. ejps.2012.01.002

Zhanga Q, Rena L, Sheng Y, Ji Y, Fu J (2010) Control of morphologies and polymorphs of calcium carbonate via multi-additives system. Mater Chem Phys 122: $156-163$ 